\title{
Priming corn seeds with plant growth regulator $^{1}$
}

\author{
Dryelle Sifuentes Pallaoro ${ }^{2 *}$, Anne Caroline Dallabrida Avelino ${ }^{2}$, \\ Elisangela Clarete Camili², Sebastião Carneiro Guimarães ${ }^{2}$, \\ Maria Cristina de Figueiredo e Albuquerque ${ }^{2}$
}

\begin{abstract}
This study aimed to evaluate the plant growth regulator application, in different doses, on priming, with and without water restriction, in corn seeds. Evaluations were carried out in two periods ( 0 to 30 days of storage), with treatments consisting of seeds primed in water $(0.0 \mathrm{MPa})$ and polyethylene glycol 6000 solution $(-0.4 \mathrm{MPa})$, with or without plant growth regulator added in different doses, plus a control group. The amount of plant growth regulator was standardized by the gibberellic acid concentration in the commercial product, adopting the doses zero, 1, 2 and $3 \mathrm{mg}$ of gibberellic acid. $\mathrm{L}^{-1}$ solution. After priming, the seeds were dried in an oven with forced air circulation for nine hours, and evaluated for water content, percentage and first count of germination, percentage of abnormal seedlings and non-germinated seeds, cold test, seedling length and dry weight and vigor index. Priming with water restriction $-0.4 \mathrm{MPa}$, in solution of polyethylene glycol 6000 , improves the vigor; however, the addition of plant growth regulator in priming does not provide increase in corn seeds quality. Corn priming in water, regardless the addition of plant growth regulator, reduces the ability of the seeds to withstand storage.

Index-terms: auxin, cytokinin, gibberellic acid, polyethylene glycol.
\end{abstract}

\section{Condicionamento de sementes de milho com reguladores vegetais}

\begin{abstract}
RESUMO - Objetivou-se avaliar a aplicação de regulador vegetal em diferentes doses via condicionamento fisiológico, com e sem restrição hídrica, em sementes de milho. Foram realizadas avaliações em dois períodos ( 0 e 30 dias de armazenamento), sendo os tratamentos compostos por sementes condicionadas em água ( $0,0 \mathrm{MPa})$ e em solução de polietilenoglicol 6000 (-0,4 MPa), com ou sem adição de regulador vegetal em diferentes doses, mais o controle. A quantidade de regulador vegetal foi padronizada pela concentração de ácido giberélico no produto comercial, adotando as doses zero, 1, 2 e $3 \mathrm{mg}$ ácido giberélico. $\mathrm{L}^{-1}$ solução. Após o condicionamento as sementes foram secas em estufa, por nove horas, e avaliadas quanto ao teor de água, porcentagem e primeira contagem da germinação, porcentagem de plântulas anormais e sementes não germinadas, teste de frio, comprimento e massa seca de plântulas e índice de vigor. O condicionamento fisiológico com restrição hídrica $-0,4 \mathrm{MPa}$, em solução de polietilenoglicol 6000 , melhora o vigor, entretanto, a adição de regulador vegetal no condicionamento fisiológico não proporciona aumento na qualidade das sementes de milho. O condicionamento de milho em água, independente da adição de regulador vegetal, reduz a capacidade das sementes resistir ao armazenamento.
\end{abstract}

Termos para indexação: ácido giberélico, auxina, citocinina, polietilenoglicol.

\section{Introduction}

In the management of corn crop, new technologies are constantly used, including the employment of enhanced cultivars associated with fungicides, nutrients or plant growth regulators application on the seeds (Silva et al., 2008), among others. In order to avoid losses during storage, seed treatment occurs with seed processing, once corn seeds have high added value. When they are not used for sowing in the production year, they are repacked and stored until the next crop, since the chemical treatment received impede the commercialization for alimentary purposes. Due to a longer storing period, seeds will be more susceptible to deterioration, thus, the adoption of new techniques such as priming and the use of plant growth regulators can be used as important tools to increase the corn seeds effectiveness in the second year.

Corn priming improves the vigor and viability increasing the germination speed and percentage, seedling length and dry mass of corn (Dezfuli et al., 2008; Yasari et al., 2013) sweet corn (Oliveira et al., 2007), sorghum (Oliveira and Gomes

${ }^{1}$ Submitted on 05/12/2016. Accepted for publication on 06/28/2016.

${ }^{2}$ Departamento de Fitotecnia e Fitossanidade, UFMT, CEP 78060-900- Cuiabá, MT, Brasil.

*Corresponding author: < dryelle_pallaoro@hotmail.com> 
Filho, 2010), and other crops. Simultaneously to priming, the seeds can be treated with plant growth regulators applied through soaking, so, in conditioning solution. Promising results were obtained with wheat seeds (Ghobadi et al., 2012), castor bean (Peixoto et al., 2011), onions (Yarnia and Tabrizi, 2012), rye (Ansari et al., 2013) and sweet corn (Rivera et al., 2011).

When hormones are produced or absorbed by the seeds, they participate in many processes. Auxin stimulates the elongation of coleoptiles and root formation; gibberellin induces germination through the activation of the embryos growth, mobilization of reserves and weakening of the endosperm layer and; cytokinins acts mainly in the control of cell division, operating in the morphogenesis of the aerial part and the roots. However, the application of exogenous cytokinins may inhibit hypocotyl elongation (Taiz and Zeiger, 2013). Regarding the application of plant growth regulators, the interval between the optimal and inhibitory levels, is narrow, so slight variations on dosage may stimulate or inhibit these products performance.

To sum up, the use of priming associated to the addition of plant growth regulators may be an alternative to increase vigor, avoiding the corn seeds disposal as well as environmental contamination. The objective of this research was to evaluate the use of plant growth regulators in different doses through priming, with and without water restriction, in corn seeds.

\section{Material and Methods}

With the intention of reproducing the farmers reality, hybrid corn seeds type DKB 390 VT PRO2 were used, chemically treated with deltamethrin, methyl primifol, metalaxyl, tiabendazole, fludioxonil, and polyoxyethylene alkyl phenol ether, yielded by Monsanto company. The experiment was performed with completely randomized design, double factorial scheme, with two evaluation periods, before storage and 30 days after storage, eight treatments and a control. The plant growth regulator used in priming was the commercial product Stimulate ${ }^{\circledR}$, constituted by gibberellic acid $\left(\mathrm{GA}_{3}\right)\left(50 \mathrm{mg}\right.$. $\left.\mathrm{L}^{-1}\right)$, kinetin $\left(90 \mathrm{mg} . \mathrm{L}^{-1}\right)$ and indolbutiric acid $\left(50 \mathrm{mg} . \mathrm{L}^{-1}\right)$.

The treatment consisted of seeds primed in water $(0.0$ $\mathrm{MPa})$ and in polyethylene glycol $6000(-0.4 \mathrm{MPa})$, with or without the addition of plant growth regulator in different doses. To standardize the quantity of plant growth regulators, the concentration of gibberellic acid in the commercial product was used as reference, adopting a zero, one dose lower and one higher than the recommended by Ghodrat and Rousta (2012). Thus, doses zero $\left(\mathrm{D}_{0}\right), 1\left(\mathrm{D}_{1}\right), 2\left(\mathrm{D}_{2}\right)$ and $3\left(\mathrm{D}_{3}\right)$ $\mathrm{mg}$ of gibberellic acid. $\mathrm{L}^{-1}$ solution were used.

The amount of PEG 6000 used in the preparation of the polyethylene glycol solution was calculated according to the Michael and Kaufmann equation (1973). Priming was performed by immersing the seeds in non-aerated solution at 24 $\pm 1{ }^{\circ} \mathrm{C}$, for 24 hours. Finally, the seeds were washed in running water, superficially dried with towel paper, transferred to Kraft paper bags for drying in forced air circulation at $40^{\circ} \mathrm{C}$, for nine hours and the control seeds were not submitted to drying. The drying period was determined in a pre-test.

Evaluation of water content were carried out by the oven method, before and after priming and after drying, using $4.5 \pm 0.5$ $\mathrm{g}$ of seeds (Brasil, 2009) with three replications; first count and germination percentage, by the germination test in towel paper roll, at $30^{\circ} \mathrm{C}$, photoperiod of 12 hours, counting the amount of normal seedlings in the $4^{\text {th }}$ and $7^{\text {th }}$ days after sowing, respectively (Brasil, 2009). After germination test, the seedlings were classified as normal (germination percentage), abnormal seedlings and non-germinated seeds. Cold test in towel paper roll were also performed, where the seeds were exposed to $10^{\circ} \mathrm{C}$ temperature for seven days. After this period, the rolls were transferred to BOD at $30^{\circ} \mathrm{C}$ for germination count in the $4^{\text {th }}$ day (Barros et al., 1999); length and seedlings dry mass in towel paper roll, with 10 seeds per roll, following the instructions of the germination test, with measuring on the $5^{\text {th }}$ day after sowing (Nakagawa, 1999); and the vigor index, calculated by the product between the germination percentage and the seedling average length (Abdul-Baki and Anderson, 1973).

After the evaluations in time zero, the remaining seeds were transferred to Kraft paper bags and stored in laboratory conditions, without the control of relative humidity and temperature (Figure 1), for 30 days, and were re-evaluated at the end. The data obtained was submitted to variance analysis and the averages compared by the Scott-Knott test $(\mathrm{P}<0.05)$.

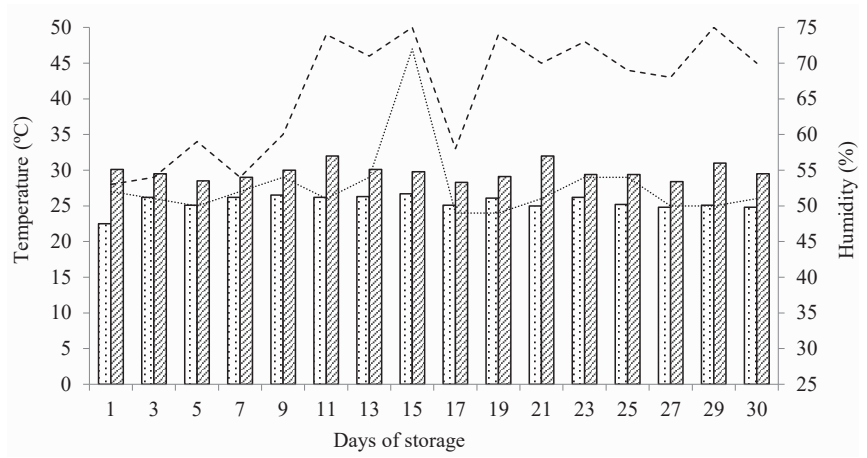

Figure 1. Room temperature $(\mathrm{T})$ and relative humidity of the air (U), minimum and maximum, during corn seed storage (Zea mays L.) under laboratory conditions. 


\section{Results and Discussion}

The water contents of the seeds after priming were higher in the treatments without the use of priming agent, indicating that polyethylene glycol was efficient in reducing the water absorption speed, restricting imbibition (Table 1). Drying the seeds for nine hours at $40^{\circ} \mathrm{C}$ reduced the water levels, however, the amount varied between the treatments, since the drying period was not enough to remove the water absorbed during priming completely. After the storage for 30 days, there was a decrease in the water level in all treatments primed with PEG, and the control had an increase in the water level, possibly by the hygroscopic balance. This situation occurs when the relative humidity of the environment is elevated, making the dry seeds to absorb water.

For the germination percentage and first counting, the interaction of the treatments and the period of storage were significant (Table 2). It was observed that, after storage, there was a reduction in the germination percentage and first count after priming in water with plant growth regulator.
Table 1. Water level (\%) of the corn seeds (Zea mays L.) submitted to priming in different water potentials $\left(\Psi_{\mathrm{w}}\right)$ through immersion in priming solution added with plant growth regulators, right after (AP - after priming, without drying), after priming and drying (time 0 ) and after storage (30 days).

\begin{tabular}{cccc}
\hline$\Psi \mathrm{w}^{*} /$ Dose & AP & 0 (zero) & 30 days \\
\hline Control & 9.7 & 9.7 & 10.3 \\
$0.0+\mathrm{D} 0$ & 32.3 & 20.6 & 11.3 \\
$0.0+\mathrm{D} 1$ & 32.8 & 20.7 & 11.4 \\
$0.0+\mathrm{D} 2$ & 32.0 & 21.1 & 11.0 \\
$0.0+\mathrm{D} 3$ & 33.5 & 19.7 & 11.5 \\
$-0.4+\mathrm{D} 0$ & 28.3 & 16.6 & 11.4 \\
$-0.4+\mathrm{D} 1$ & 28.8 & 16.9 & 11.3 \\
$-0.4+\mathrm{D} 2$ & 28.2 & 16.3 & 11.3 \\
$-0.4+\mathrm{D} 3$ & 29.9 & 17.2 & 11.1 \\
\hline
\end{tabular}

* $\Psi_{\mathrm{w}}$ : water potential in MPa.

Table 2. Percentage (GP) and first germination count (FGC), percentage of abnormal seedlings (AS) and non-germinated seeds (NGS) of corn (Zea mays L.) submitted to priming with plant growth regulators in different doses after priming and drying (time zero) and after storage (30 days).

\begin{tabular}{|c|c|c|c|c|c|c|c|c|}
\hline \multirow{3}{*}{$\Psi_{\mathrm{w}^{*}}$} & \multicolumn{2}{|c|}{ GP (\%) } & \multicolumn{2}{|c|}{ FGC (\%) } & \multicolumn{2}{|c|}{ AS (\%) } & \multicolumn{2}{|c|}{ NGS (\%) } \\
\hline & 0 & 30 & 0 & 30 & 0 & 30 & 0 & 30 \\
\hline & \multicolumn{8}{|c|}{ days } \\
\hline Control & $90.7 \mathrm{bA}$ & $88.0 \mathrm{bA}$ & $89.0 \mathrm{bA}$ & $83.0 \mathrm{bA}$ & 3.0 & 5.0 & 6.3 & 7.0 \\
\hline $0.0+\mathrm{D}_{0}$ & $90.0 \mathrm{bA}$ & $85.0 \mathrm{bA}$ & $85.5 \mathrm{bA}$ & $81.0 \mathrm{bA}$ & 6.0 & 6.5 & 4.0 & 8.5 \\
\hline $0.0+\mathrm{D}_{1}$ & $95.0 \mathrm{aA}$ & $79.0 \mathrm{cB}$ & $92.0 \mathrm{aA}$ & $78.0 \mathrm{bB}$ & 3.5 & 6.5 & 1.5 & 14.5 \\
\hline $0.0+\mathrm{D}_{2}$ & $88.5 \mathrm{bA}$ & $71.0 \mathrm{~dB}$ & $82.0 \mathrm{bA}$ & $68.0 \mathrm{cB}$ & 5.0 & 8.5 & 6.5 & 20.5 \\
\hline $0.0+\mathrm{D}_{3}$ & $87.5 \mathrm{bA}$ & $72.5 \mathrm{~dB}$ & $86.0 \mathrm{bA}$ & $71.5 \mathrm{cB}$ & 3.0 & 7.0 & 9.5 & 20.5 \\
\hline$-0.4+\mathrm{D}_{0}$ & $96.0 \mathrm{aA}$ & $97.0 \mathrm{aA}$ & $95.0 \mathrm{aA}$ & $96.0 \mathrm{aA}$ & 1.0 & 0.0 & 3.0 & 3.0 \\
\hline$-0.4+\mathrm{D}_{1}$ & $97.0 \mathrm{aA}$ & $97.0 \mathrm{aA}$ & $96.0 \mathrm{aA}$ & $96.0 \mathrm{aA}$ & 1.5 & 0.5 & 1.5 & 2.5 \\
\hline$-0.4+\mathrm{D}_{2}$ & $99.0 \mathrm{aA}$ & $93.5 \mathrm{aA}$ & $97.5 \mathrm{aA}$ & $92.5 \mathrm{aA}$ & 0.5 & 2.0 & 0.5 & 4.5 \\
\hline$-0.4+\mathrm{D}_{3}$ & $98.5 \mathrm{aA}$ & $92.0 \mathrm{aA}$ & $96.0 \mathrm{aA}$ & $90.5 \mathrm{aA}$ & 0.0 & 1.5 & 1.5 & 6.5 \\
\hline Average & $93.6 \mathrm{~A}$ & $86.1 \mathrm{~B}$ & $91.0 \mathrm{~A}$ & $84.0 \quad \mathrm{~B}$ & - & - & - & - \\
\hline $\mathrm{CV}(\%)$ & \multicolumn{2}{|c|}{5.2} & \multicolumn{2}{|c|}{5.5} & \multicolumn{2}{|c|}{-} & \multicolumn{2}{|c|}{-} \\
\hline
\end{tabular}

* $\Psi$ w: water potential in MPa; CV: coefficient of variation

Averages followed by the same letter, lower case in the column and upper case in the lines, do not differ statistically between themselves, by the Scott-Knott test $(\mathrm{P}<0.05)$.

Priming without water restriction associated with the use of plant growth regulators in the solution $\left(0.0+\mathrm{D}_{1} ; 0.0+\mathrm{D}_{2}\right.$; $0.0+\mathrm{D}_{3}$ ), possibly made the seeds more sensible to storage, once it has been a decrease in the germination percentage and first count and an increase in the non-germinated seeds after 30 days of storage (Table 2). This effect was not observed in the seed primed in water without plant growth regulator $\left(0.0+\mathrm{D}_{0}\right)$ showing that the decrease occurred due to the plant growth regulator addition.
Besides this, the quality decrease was intensified in treatments without water restriction and with the highest doses of plant growth regulators, where the amount of non-germinated seeds has passed from $7 \%$ in the control, after storage, to $20.5 \%$ in $\mathrm{D}_{2}$ and $\mathrm{D}_{3}$ doses. This result may be associated with a higher absorption of the plant growth regulator during the immersion period once the application of plant growth regulator might accelerate the development, such as seed deterioration. 
In jacaranda, it was observed that seed immersion in gibberellic acid solution caused a decrease in the seedlings emergence percentage. The authors affirmed that after the treatment and in the beginning of storage, the seeds probably had enough endogenous gibberellin, thus, the supplementation with plant growth regulator may have unleashed an inhibitory effect (Scalon et al., 2006). Furthermore, the application of gibberellin may produce a contrary effect, accelerating the deterioration process, compromising the seeds physiological potential (Marcos-Filho, 2015).

In sweet corn, seed immersion in gibberellic acid solution generated improvements in viability and vigor until 60 days of storage (Rivera et al., 2011). Beneficial effects were also observed in wheat seeds (Ghobadi et al., 2012) and rye (Ansari et al., 2013). In this study, however, priming without water restriction, associated with the use of plant growth regulators, caused decrease of the germination percentage and first count, with the effect being intensified after storage.

Regarding priming with water restriction, in polyethylene glycol 6000 solution $(-0.4 \mathrm{MPa})$ there was no differences between the doses of plant growth regulators used and, after 30 days of storage, the treatments kept the germination percentage and first count above $90 \%$. Comparing the averages after priming and after storage, all priming treatments in polyethylene glycol were higher than the control (Table 2) showing gains in seed vigor and viability.

For the percentage of abnormal seedlings (Table 2) it was evident that the priming process with water restriction (PEG 6000 -0.4 MPa), regardless the addition of plant growth regulator, decreased the occurrence of abnormalities in seedlings. This may be associated to the reduction of water absorption speed of the seeds, decreasing the soaking damage. In this process, the risks of damage in the embryo axis caused by rapid water absorption are reduced, since the tissues develop in a more organized way (Menezes et al., 2006). Studying corn drying, Rosa et al. (2000) observed that the water absorption process in dry seeds may cause damage, and the damage intensity is related to the initial quality.

In the cold test, priming with polyethylene glycol, without plant growth regulators $\left(-0.4+\mathrm{D}_{0}\right)$, with regulator in the smallest dose $\left(-0.4+\mathrm{D}_{1}\right)$, and the control treatment were superior in both evaluated periods and the other treatments showed low germination, especially after storage (Table 3 ). Sweet corn seeds, primed in water with gibberellic acid and stored, when submitted to the cold test, showed drastic decrease in physiological potential. This possibly occurred since gibberellic acid acts in the reserve mobilization and weakening of the endosperm layer (Rivera et al., 2011), and it may accelerate the deterioration process (Marcos-Filho, 2015) reducing the seed capacity to withstand storage.

Table 3. Germination after cold test (CT), seedling length (SL), seedling dry mass (SDM) and vigor index (VI) in corn seeds (Zea mays L.) submitted to priming with plant growth regulators in different doses after priming and drying (time zero) and after storage (30 days).

\begin{tabular}{|c|c|c|c|c|c|c|c|c|}
\hline \multirow[t]{3}{*}{$\Psi \mathrm{w}^{*}$} & \multicolumn{2}{|c|}{ CT (\%) } & \multicolumn{2}{|c|}{ SL $\left(\mathrm{cm}\right.$. seedling ${ }^{-1}$ ) } & \multicolumn{2}{|c|}{ SDM (mg. seedling ${ }^{-1}$ ) } & \multicolumn{2}{|c|}{ VI } \\
\hline & 0 & 30 & 0 & 30 & 0 & 30 & 0 & 30 \\
\hline & \multicolumn{2}{|c|}{ days } & \multicolumn{2}{|c|}{ days } & \multicolumn{2}{|c|}{ days } & \multicolumn{2}{|c|}{ days } \\
\hline Control & $88.5 \mathrm{aA}$ & $83.0 \mathrm{aA}$ & $38.8 \mathrm{bA}$ & $35.9 \mathrm{aB}$ & $66.7 \mathrm{aA}$ & $56.9 \mathrm{aB}$ & $3.524 \mathrm{bA}$ & $3.159 \mathrm{bB}$ \\
\hline $0.0+\mathrm{D}_{0}$ & $82.5 \mathrm{bA}$ & $71.5 \mathrm{bB}$ & $41.7 \mathrm{aA}$ & $36.1 \mathrm{aB}$ & $66.6 \mathrm{aA}$ & $55.0 \mathrm{aB}$ & $3.753 \mathrm{aA}$ & $3.069 \mathrm{bB}$ \\
\hline $0.0+\mathrm{D}_{1}$ & $78.5 \mathrm{bA}$ & $49.0 \mathrm{~dB}$ & $38.2 \mathrm{bA}$ & $37.5 \mathrm{aA}$ & $58.1 \mathrm{bA}$ & $60.6 \mathrm{aA}$ & $3.631 \mathrm{bA}$ & $2.965 \mathrm{bB}$ \\
\hline $0.0+\mathrm{D}_{2}$ & $76.0 \mathrm{bA}$ & $53.0 \mathrm{~dB}$ & $43.5 \mathrm{aA}$ & $37.3 \mathrm{aB}$ & $66.4 \mathrm{aA}$ & $58.4 \mathrm{aB}$ & $3.853 \mathrm{aA}$ & $2.655 \mathrm{cB}$ \\
\hline $0.0+\mathrm{D}_{3}$ & $60.0 \mathrm{cA}$ & $62.5 \mathrm{cA}$ & $42.1 \mathrm{aA}$ & $32.2 \mathrm{bB}$ & $65.3 \mathrm{aA}$ & $51.3 \mathrm{aB}$ & $3.681 \mathrm{bA}$ & $2.325 \mathrm{~dB}$ \\
\hline$-0.4+\mathrm{D}_{0}$ & $93.5 \mathrm{aA}$ & $86.0 \mathrm{aA}$ & $39.9 \mathrm{bA}$ & $33.6 \mathrm{bB}$ & $65.0 \mathrm{aA}$ & $54.0 \mathrm{aB}$ & $3.835 \mathrm{aA}$ & $3.255 \mathrm{aB}$ \\
\hline$-0.4+\mathrm{D}_{1}$ & $90.0 \mathrm{aA}$ & $86.0 \mathrm{aA}$ & $38.7 \mathrm{bA}$ & $35.3 \mathrm{aB}$ & $64.2 \mathrm{aA}$ & $55.7 \mathrm{aB}$ & $3.761 \mathrm{aA}$ & $3.424 \mathrm{aB}$ \\
\hline$-0.4+\mathrm{D}_{2}$ & $84.0 \mathrm{bA}$ & $62.0 \mathrm{cB}$ & $39.4 \mathrm{bA}$ & $35.9 \mathrm{aB}$ & $59.7 \mathrm{bA}$ & $59.9 \mathrm{aA}$ & $3.897 \mathrm{aA}$ & $3.361 \mathrm{aB}$ \\
\hline$-0.4+\mathrm{D}_{3}$ & $85.0 \mathrm{bA}$ & $76.0 \mathrm{bA}$ & $39.4 \mathrm{bA}$ & $36.5 \mathrm{aB}$ & $61.6 \mathrm{bA}$ & $60.2 \mathrm{aA}$ & $3.884 \mathrm{aA}$ & $3.358 \mathrm{aB}$ \\
\hline
\end{tabular}

* $\Psi$ water potential in MPa; $\mathrm{CV}$ : coefficient of variation;

Averages followed by the same letter, lower case in the column and upper case in the lines, do not differ statistically between themselves, by the Scott-Knott test $(\mathrm{P}<0.05)$.

Comparing seeds primed in PEG without plant growth regulator $\left(-0.4+\mathrm{D}_{0}\right)$, after cold test in time zero, with the control and the treatments $-0.4+\mathrm{D}_{1}, 0.0+\mathrm{D}_{0}$, it was observed an absolute increase of five percentage points in germination, that can be given to the restriction in water absorption velocity.
On the other hand, the addition of plant growth regulator decreased this effect with the increase of the dose (Table 3 ). The increment in germination may be related to a decrease in soaking damage during the water absorption process.

Seeds soaked in polyethylene glycol solution absorb water 
slowly, which allows more time to the plasmatic membrane for rearrange, avoiding the leakage of cellular content, reducing the occurrence of soaking damage (Menezes et al., 2006).

In the seedling length, after priming, the seeds primed in water without plant growth regulator $\left(\mathrm{D}_{0}\right)$ or with regulator in doses $\mathrm{D}_{2}$ and $\mathrm{D}_{3}$ showed bigger seedlings when compared to the other treatments (Table 3). After storage, all treatments had a decrease in seedling length, except priming in water with plant growth regulator in the smallest dose $\left(0.0+\mathrm{D}_{1}\right)$.

Observing the data of seedling dry mass, the priming in water and in polyethylene glycol with plant growth regulator $\left(0.0+\mathrm{D}_{1} ;-0.4+\mathrm{D}_{2} ;-0.4+\mathrm{D}_{3}\right)$ were lower than the others before storage, however, they kept the dry mass after 30 days, while the others showed reduction in mass.

In contrast with the data from this study, Ghodrat and Rousta (2012) and Ghobadi et al., (2012), obtained increase in seedling length and dry mass when priming corn and wheat seeds, respectively, in water and with addition of gibberellic acid. Ghobadi et al. (2012) state that priming of wheat seeds in PEG -0.3 MPa for 12 hours elevates germination as well as root and shoot length and dry mass. Similar results were found by Chauhan et al. (2009) in Vigna mungo and Macrotyloma uniflorum seeds.

Therefore, different responses obtained for seedling length and dry mass may have been influenced by the absence of light and the exogenous amount of plant growth regulators in the treatments, since this test was performed in the dark and the product used was composed by gibberellin, auxin and cytokinins in different concentrations. According to Taiz and Zeiger (2013), the level of endogenous auxin in the elongation region of a healthy normal plant is near the optimum for growth, the plant sprinkling with exogenous auxin results in a modest and brief growth stimulus, sometimes even inhibitory, when growing in the dark.

For vigor index, in time zero, all treatments were higher than the control, except for priming without water restriction with plant growth regulator in doses $\mathrm{D}_{1}$ and $\mathrm{D}_{3}$. After 30 days of storage, the higher vigor indexes were obtained in treatments with priming in polyethylene glycol regardless the addiction of plant growth regulators $\left(-0.4+\mathrm{D}_{0} ;-0.4+\mathrm{D}_{1} ;-0.4\right.$ $\left.+\mathrm{D}_{2} ;-0.4+\mathrm{D}_{3}\right)$, however, all treatments showed decrease in quality when confronted the vigor index data in time zero and 30 days of storage (Table 3 ).

According to the evaluations, priming with water restriction $(-0.4 \mathrm{MPa})$ enabled improvements in the physiological quality of corn seeds regardless the addition of plant growth regulator in the polyethylene glycol 6000 solution. The seeds primed without water restriction showed decrease in the capacity of resist the storage, and this effect was pronounced with the addition of plant growth regulator to the priming.

\section{Conclusions}

Priming with water restriction $-0.4 \mathrm{MPa}$, in polyethylene glycol 6000, increases corn seed vigor.

The addition of plant growth regulators in priming does not improve corn seed quality.

Priming of corn seeds in water, regardless the addition of plant growth regulators, reduces storage resistance capacity of the seeds.

\section{Acknowledgements}

CAPES, for the master's scholarship.

\section{References}

ABDUL-BAKI, A.A.; ANDERSON, J.D. Vigour determination in soybean seed by multiple criteria. Crop Science, v.13, p.630-633, 1973. https:// dl.sciencesocieties.org/publications/cs/pdfs/13/6/CS0130060630

ANSARI, O.; AZADI, M.S.; SHARIF-ZADEH, F.; YOUNESI, E. Effect of hormone priming on germination characteristics and enzyme activity of mountain rye (Secale montanum) seeds under drought stress conditions. Journal of Stress Physiology \& Biochemistry, v.9, n.3, p.61-71, 2013. http:// www.jspb.ru/issues/2013/N3/JSPB_2013_3_61-71.pdf

BARROS, A.S.R.; DIAS, M.C.L.L.; CÍCERO, S.M.; KRZYZANOWSKI, F.C. Teste de frio. In: KRZYZANOWSKI, F.C.; VIEIRA, R.D.; FRANÇANETO, J.B. (Ed.). Vigor de sementes: conceitos e testes. Londrina: ABRATES, 1999. 218p.

BRASIL. Ministério da Agricultura, Pecuária e Abastecimento. Regras para análise de sementes. Ministério da Agricultura, Pecuária e Abastecimento. Secretaria de Defesa Agropecuária. Brasília: MAPA/ACS, 2009, 395p. http:// www.agricultura.gov.br/arq_editor/file/2946_regras_analise_sementes.pdf

CHAUHAN, J.S.; TOMAR, Y. K.; SINGH, N. I.; ALI, S.; DEBARATI. Effect of growth hormones on seed germination and seedling growth of black gram and horse gram. Journal of American Science, v.5, p.78-84, 2009. http://www.jofamericanscience.org/journals/amsci/0505/10_0901_growth_ hormones_am0505.pdf

DEZFULI, P. M.; SHARIF-ZADEH, F.; JANMOHAMMADI, M. Influence of priming techniques on seed germination behavior of maize inbred lines (Zea mays L.). Journal of Agricultural and Biological Science, v.3, n.3, p.22-25, 2008. http://www.arpnjournals.com/jabs/research_papers/rp_2008/ jabs_0508_79.pdf

GHOBADI, M.; ABNAVI, M.S.; HONARMAND, S.J.; GHOBADI, M.E.; MOHAMMADI, G.R. Effect of hormonal priming ( $\left.\mathrm{GA}_{3}\right)$ and osmopriming on behavior of seed germination in wheat (Triticum aestivum L.). Journal of Agricultural Science, v.4, n.9, p.244-250, 2012. http://www.ccsenet.org/ journal/index.php/jas/article/view/17829

GHODRAT, V.; ROUSTA, M.J. Effect of priming with gibberellic acid $\left(\mathrm{GA}_{3}\right)$ on germination and growth of corn (Zea mays L.) under saline conditions. International Journal of Agriculture and Crop Sciences, v.4, n.13, p.882-885, 2012. http://ijagcs.com/wp-content/uploads/2012/09/882-885.pdf 
MARCOS-FILHO, J. Fisiologia de sementes de plantas cultivadas. Piracicaba: FEALQ, 2015. 659p.

MENEZES, N. L.; ESPINDOLA, M. C. G.; PASQUALI, L. L.; SANTOS, C. M. R.; FRANZIN, S. M. Associação de tratamentos pré-germinativos em sementes de alface. Revista da Faculdade de Zootecnia, Veterinária e Agronomia, v.13, n.1, p.1-11, 2006. http://revistaseletronicas.pucrs.br/ojs/ index.php/fzva/article/view/2334/1821

MICHAEL, B. E.; KAUFMANN, M. R. The osmotic potential of polyethylene glicol 6000. Plant Physiology, v.51, p.914-916, 1973.

NAKAGAWA, J. Testes de vigor baseados no desempenho das plântulas. In: KRZYZANOSWKI, F.C.; VIEIRA, R.D.; FRANÇA-NETO, J.B. (Eds.). Vigor de sementes: conceitos e testes. Londrina: ABRATES, 1999, p.2.1-2.24.

OLIVEIRA, A.B.; GOMES-FILHO, E. Efeito do condicionamento osmótico na germinação e vigor de sementes de sorgo com diferentes qualidades fisiológicas. Revista Brasileira de Sementes, v.32, n.3, p. 25-34, 2010. http:// www.scielo.br/pdf/rbs/v32n3/v32n3a03.pdf

OLIVEIRA, A.S.; SILVA-MANN, R.; SANTOS, M.F.; GOIS, I.B.; BARRETTO, M.C.V. Condicionamento osmótico em sementes de milho doce submetidas ao armazenamento. Revista Ciência Agronômica, v.38, n.4, p.444-448, 2007. http://ccarevista.ufc.br/seer/index.php/ccarevista/article/ view/108/103

PEIXOTO, C.P.; SALES, F.J.S.; VIEIRA, E.L.; PASSOS, A.R.; SANTOS, J.M.S. Ação da giberelina em sementes pré-embebidas de mamoneira. Comunicata Scientiae, v.2, n.2, p.70-75, 2011. http://comunicatascientiae. com.br/comunicata/article/view/31/74

RIVERA, A.A.C.; PINHO, R.G.V.; GUIMARÃES, R.M.; VEIGA, A.D.; PEREIRA G.L.; PINHO, I.V. Efeito do ácido giberélico na qualidade fisiológica de sementes redondas de milho doce, sob diferentes condições de armazenamento. Revista Brasileira de Milho e Sorgo, v.10, n.3, p.247-256, 2011. http://ainfo. cnptia.embrapa.br/digital/bitstream/item/104328/1/Efeito-acido.pdf
ROSA, S.D.V.S.; PINHO, E.V.R.V.; VIEIRA, M.G.G.C.; VEIGA, R.D. Eficácia do teste de condutividade elétrica para uso em estudos de danos de secagem em sementes de milho. Revista Brasileira de Sementes, v.22, n.1, p.54-63, 2000. http://www.abrates.org.br/revista/artigos/2000/v22n1/ artigo09.pdf

SCALON, S.P.Q.; MUSSURY, R.M.; SCALON FILHO, H.; FRANCELINO, C.S.F.; FLORENCIO, D.K.A. Armazenamento e tratamentos prégerminativos em sementes de jacarandá (Jacaranda cuspidifolia Mart.). Revista Árvore, v.30, n.2, p.179-185, 2006. http://www.scielo.br/scielo. php?script=sci_arttext\&pid=S0100-67622006000200004

SILVA, T.T.A.; PINHO, E.R.V.; CARDOSO, D.L.; FERREIRA, C.A.; ALVIM, P.L.; COSTA, A.A.F. Qualidade fisiológica de sementes de milho na presença de bioestimulantes. Ciência e Agrotecnologia, v.32, n.3, p.840-846, 2008. http://www.scielo.br/scielo.php?script=sci arttext\&pid=S1413-70542008000300021

TAIZ, L.; ZEIGER, E. Fisiologia vegetal. 5 ed. Porto Alegre: Artmed, 2013. 954p.

YARNIA, M., TABRIZI, E.F.M. Effect of seed priming with diferente concentration of $\mathrm{GA}_{3}$, IAA and kinetin on Azarshahr onion germination and seedling growth. Journal of Basic and Applied Scientific Research, v.3, n.2, p.2657-2661, 2012. http://www.textroad.com/pdf/JBASR/J.\%20Basic.\%20 Appl.\%20Sci.\%20Res.,\%202(3)2657-2661,\%202012.pdf

YASARI, E.; SORAKI, S.Y.; SARAVI, K.O. Appraisal of the effects of osmopriming and hydro-priming treatments on the seeds of corn (Zea mays L.) cultivars. International Journal of Agronomy and Plant Production, v.4, p.195203, 2013. http://www.cabi.org/cabdirect/FullTextPDF/2013/20133097525.pdf 